\title{
Synthesis and Pharmacological Evaluation of New 16-Methyl Pregnane Derivatives
}

\author{
Elena Ramirez, ${ }^{a}$ Marisa Cabeza, ${ }^{b}$ Ivonne Heuze,${ }^{b}$ Edgar Gutiérrez,${ }^{b}$ Eugene Bratoeff,,${ }^{* a}$ \\ Marisol Membrillo, ${ }^{a}$ and Alfonso LirA ${ }^{a}$ \\ Department of Pharmacy, Faculty of Chemistry ${ }^{a}$ UNAM, Ciudad Universitaria, 04510 Mexico D. F., Mexico and \\ Department of Biological Systems and Animal Production, Metropolitan University, ${ }^{b}$ Mexico D. F., Mexico. \\ Received June 4, 2001; accepted August 20, 2001
}

The pharmacological activity of several new pregnane derivatives 15-19 were determined on gonadectomized male hamster flank organs, seminal vesicles and in vitro conversion of testosterone (T) to dihydrotestosterone (DHT) as 5 $\alpha$-reductase inhibitors. Steroids 15-19 decreased the diameter of the pigmented spot in the flank organs as compared to the $T$ treated animals; in this model, steroids 16 and 19 showed a higher activity than the commercially available finasteride 3 . Injection of $T$ increased the weight of the seminal vesicles. Compounds 15-19 when injected together with $T$ decreased the weight of the seminal vesicles thus showing an antiandrogenic effect. The trienone 19 exhibited a considerably higher activity than finasteride. Steroids $15-19$ inhibited the in vitro metabolism of $\left[{ }^{3} \mathrm{H}\right] \mathrm{T}$ to $\left[{ }^{3} \mathrm{H}\right] \mathrm{DHT}$ in seminal vesicles homogenates of gonadectomized male hamsters. Compounds 18 and 19 showed a much higher antiandrogenic effect than finasteride. This enhancement of the biological activity could probably be attributed to the coplanarity of the steroidal skeleton as previously observed by our group. The high antiandrogenic activity of the epoxy compound 16 is probably the result of the ring opening of the oxiran ring with the nucleophilic part of the enzyme $5 \alpha$-reductase thus leading to a stable adduct with concomitant deactivation of this enzyme.

Key words flank organ; seminal vesicle; $5 \alpha$-reduction; testosterone conversion; C-16 substituent

The androgen metabolism of human prostate is regulated by a variety of androgen metabolizing enzymes. ${ }^{1)}$ Among those, the $5 \alpha$-reductase enzyme possesses the highest potential activity. ${ }^{2)}$ It converts testosterone (T) 1 (Fig. 1) into the more potent androgen dihydrotestosterone (DHT) 2.3) Thus $5 \alpha$-reductase dictates the cellular availability of DHT and consequently the androgen responsiveness of the human prostate. As a result of this, several new clinically useful inhibitors for the treatment of benign prostatic hyperplasia and male pattern baldness were developed shortly after the discovery of the enzyme $5 \alpha$-reductase.

Recently several new inhibitors of $5 \alpha$-reductase were described as potential clinical candidates for the treatment of benign prostatic hyperplasia. These compounds (Fig. 1) include finasteride $3,{ }^{4,5)}$ epristeride $4,{ }^{6)}$ cyproterone acetate 5, ${ }^{7}$ BOMT $\mathbf{6}^{8)}$ and FCE 282607 7. $^{9)}$ Finasteride 3 inhibits the conversion of T $\mathbf{1}$ to DHT $\mathbf{2}$ in epithelium and stroma of human benign prostatic hyperplasia. ${ }^{10}$ This steroid has a greater affinity for $5 \alpha$-reductase type 2 than for the type 1 enzyme, ${ }^{11)}$ both present in the human prostate. ${ }^{12)}$ The type 2 isozyme, is the dominant form in genital tissue, however, the exact physiological roles of these enzymes has yet to be fully elucidated.

In this study we evaluated the following new steroidal compounds as $5 \alpha$-reductase inhibitors: 15-19 (Figs. 2, 3). The pharmacological evaluation was determined in flank organs, seminal vesicles and the effect of the new steroidal compounds on the in vitro metabolism of $\left[{ }^{3} \mathrm{H}\right] \mathrm{T}$ to $\left[{ }^{3} \mathrm{H}\right] \mathrm{DHT}$ in seminal vesicle homogenates of gonadectomized male hamsters. ${ }^{13)}$

Flank organs are pilosebaceous structures androgen dependent. In males, these glands measure $8 \mathrm{~mm}$ and shrink upon castration, ${ }^{13,14)}$ until they look as those of females: however daily injections of $\mathbf{1}$ or $\mathbf{2}$ restores their original size. ${ }^{13-16)}$ The presence of $5 \alpha$-reductase in flank organs as well the in- hibition of this enzyme by finasteride has been demonstrated several years ago. ${ }^{13,16-18)}$ Many steroidal and non steroidal compounds have been evaluated as antiandrogens using the flank organs as a model. ${ }^{16)}$

Seminal vesicles are male accessory glands that are also androgen dependent. These organs are capable of reducing 1 to $\mathbf{2}$ in both intact and gonadectomized animals and have also been used for evaluation of steroidal and non-steroidal compounds as antiandrogens. ${ }^{13,17)}$

\section{Chemistry}

Synthesis of Steroids 15-19 Steroids 15-19 were prepared from the commercially available 16-dehydropregnenolone acetate $\mathbf{8}$. Epoxidation of the double bond at C-16 in $\mathbf{8}$ with hydrogen peroxide and sodium hydroxide afforded the epoxy derivative 9 (Fig. 2). Acetylation of 9 in the usual manner yielded the acetoxy compound 10. The protection of the carbonyl group in $\mathbf{1 0}$ was effected with ethylene glycol, trimethyl orthoformate and $p$-toluenesulfonic acid (PTS). The resulting dioxolane derivative $\mathbf{1 1}$ was allowed to reflux with methylmagnesium chloride in tetrahydrofuran (THF); this reaction afforded the 16-methyl substituted dioxolane derivative 12 (Fig. 2). Hydrolysis of the dioxolane ring in $\mathbf{1 2}$ to recover the carbonyl moiety was carried out with PTS in acetone thus forming the carbonyl derivative 13. The oxidation of the hydroxyl group at C-3 in $\mathbf{1 3}$ was effected with lithium carbonate, lithium bromide and bromine in $N, N$-dimethylformamide (DMF) thus affording the 4,6-diene-3,20-dione moiety 14. Esterification of the hydroxyl group in $\mathbf{1 4}$ with trifluoroacetic anhydride and valeric acid yielded the desired valeroyloxy derivative $\mathbf{1 5}$.

Treatment of $\mathbf{1 3}$ with 2,3-dichloro-5,6-dicyanobenzoquinone (DDQ) in dioxan (Fig. 3) afforded the triene-dione compound 18, which upon esterification with valeric acid yielded the ester 19 . 

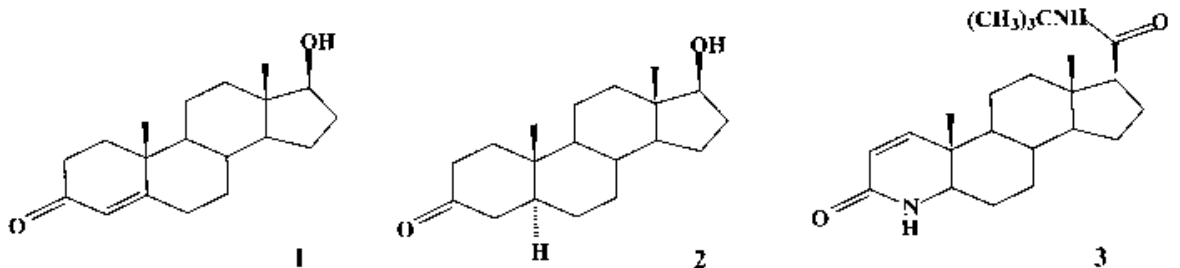<smiles>CCCCC(=O)[C@@H]1CCC2C3CC=C4C=C(C(=O)O)CCC4(C)[C@H]3CC[C@]21C</smiles><smiles>CC12CCC3C(CCC4OC(=O)CC[C@@]43C)C1CC[C@]2(C)O</smiles><smiles>CC12C=CC(=O)NC1CCC1C3CCC(C(=O)NC(C)(C)C(F)(F)C(F)(F)c4ccccc4)C3CCC12</smiles>

Fig. 1. Steroids Structures<smiles>CO[C@H]1CC[C@]2(C)C(=CCC3C2CC[C@]2(C)C(C(C)=O)=CCC32)C1</smiles><smiles>CC(=O)[C@@]1(C)C[C@H]2[C@H]1CC1C3CC=C4CC(O)CC[C@]4(C)C3CC[C@@]12C</smiles><smiles>CC(=O)C1CCC2(C(C)=O)C1CC1C3CC=C4CC(C#N)CCC4(C)C3CCC12C</smiles><smiles>CC(=O)[C@]1(O)[C@@H](C)CC2C3CC=C4CC(O)CCC4(C)C3CC[C@]21C</smiles>

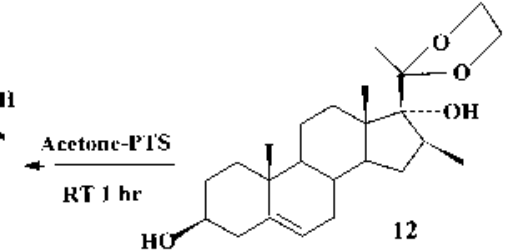

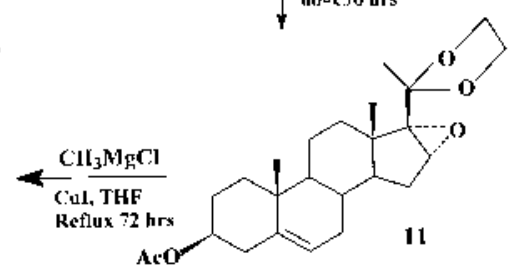

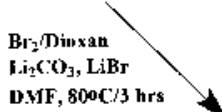<smiles>CC(C)CC(C)C</smiles><smiles>CCC(C)(C)O[C@H](C)OC(=O)O</smiles>
PTS, RT, 1.5 brs

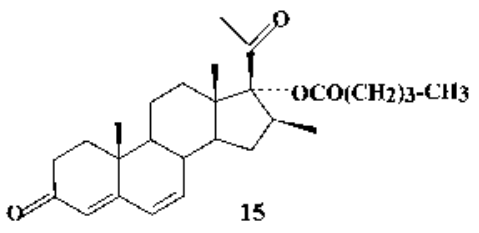

Fig. 2. Synthesis of New Steroids

The epoxidation of the double bond at C-6 in 15 (Fig. 3) was carried out with $m$-chloroperbenzoic acid in chloroform. The resulting epoxy compound $\mathbf{1 6}$ was treated with hydrobromic acid in acetic acid to give the desired 6-bromo derivative 17.

\section{Biological Activity}

The biological activity of steroids $\mathbf{1 5}-\mathbf{1 9}$ was determined in gonadectomized male hamsters divided in several groups. The animals in the control group were injected with the vehicle (sesame oil); in the other groups the hamsters were treated with $\mathbf{1}^{17)}$ a combination of $\mathrm{T}$ with finasteride 3 or $\mathrm{T}$ with the new steroids. After $6 \mathrm{~d}$ of treatment, the animals 
15

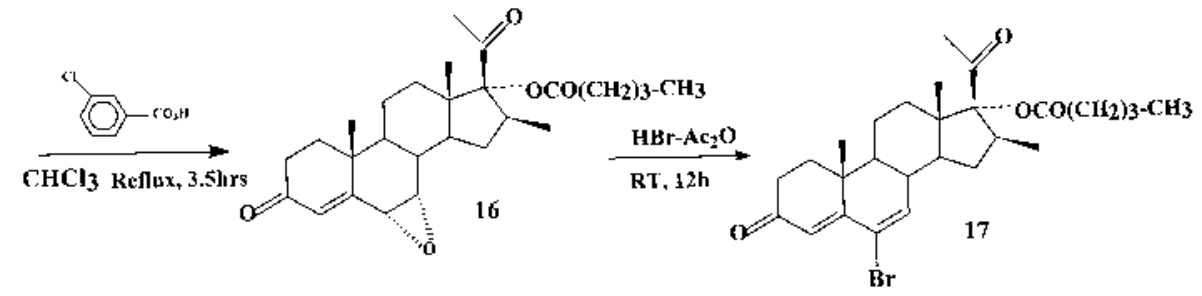

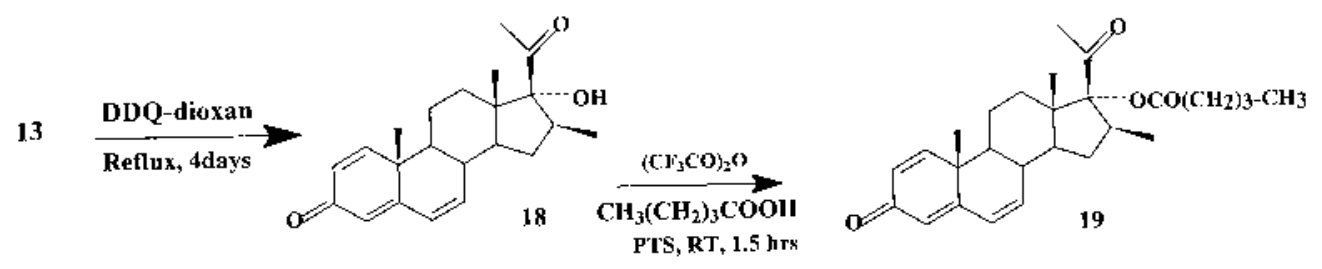

Fig. 3. Synthesis of New Steroids

Table 1. The Diameter of Flank Organs and the Weight of Seminal Vesicles Were Measured from Animals That Received sc Treatments of C-16 Substituted Steroids

\begin{tabular}{cccc}
\hline \hline & $\begin{array}{c}\text { Treatment } \\
(\mathrm{mg})\end{array}$ & $\begin{array}{c}\text { Diameter of the } \\
\text { pigmented spot } \\
(\mathrm{mm})\end{array}$ & $\begin{array}{c}\text { Weight of seminal } \\
\text { vesicles } \\
(\mathrm{mg})\end{array}$ \\
\hline Control & & $2.75 \pm 0.05$ & $177.45 \pm 30.7$ \\
$\mathrm{~T}$ & 0.2 & $4.25 \pm 0.50$ & $317.83 \pm 30.1$ \\
$\mathrm{~T}+\mathbf{3}$ & 0.2 & $3.00 \pm 0.02$ & $216.00 \pm 27.8$ \\
$\mathrm{~T}+\mathbf{1 5}$ & 0.2 & $3.00 \pm 0.00$ & $265.15 \pm 30.4$ \\
$\mathrm{~T}+\mathbf{1 6}$ & 0.2 & $2.00 \pm 0.00$ & $208.75 \pm 24.5$ \\
$\mathrm{~T}+\mathbf{1 7}$ & 0.2 & $3.00 \pm 0.50$ & $246.00 \pm 49.1$ \\
$\mathrm{~T}+\mathbf{1 8}$ & 0.2 & $3.00 \pm 0.50$ & $231.25 \pm 35.2$ \\
$\mathrm{~T}+\mathbf{1 9}$ & 0.2 & $1.80 \pm 0.50$ & $202.00 \pm 30.1$ \\
\hline
\end{tabular}

The results are given mean \pm standard deviation.

were anesthesized with ether and sacrificed.

Flank Organs The diameter of the pigmented spot on the flank organs of the control animals (vehicle treated), T $\mathbf{1}$, finasteride $\mathbf{3}$ and with the new steroids treated animals is shown in Table 1 . T significantly increased $(p<0.05)$ the diameter of the pigmented spot $(4.25 \mathrm{~mm})$ whereas finasteride decreased it $(p<0.005)(3 \mathrm{~mm})$. The new steroids 15-19 decreased the diameter of the pigmented spot as compared to $\mathrm{T}$, thus suggesting an inhibitory effect on the enzyme $5 \alpha$-reductase and also the presence of an antiandrogenic effect. The most effective compound in this model was steroid 19 which reduced the diameter of the pigmented spot on the flank organs to $1.8 \mathrm{~mm}$.

Seminal Vesicles After castration, the weight of the seminal vesicles of the male hamsters significantly decreased $(p<.05)$ as compared to that of the normal glands. Treatment with vehicle alone (control) did not change this condition whereas subcutaneous injection of $200 \mu \mathrm{g}$ of 1 for $6 \mathrm{~d}$ significantly increased $(p<0.05)$ the weight of the seminal vesicles in castrated male hamsters $(317 \mathrm{mg})$ (Table 1$)$. When $\mathbf{1}$ and finasteride 3 were injected together, the weight of the seminal vesicles decreased $(216 \mathrm{mg})$. The injection of steroids 1519 together with $\mathrm{T}$ decreased $(p<0.005)$ the weight of the seminal vesicles as compared to the $T$ treated hamsters thus suggesting an inhibitory effect on $5 \alpha$-reductase enzyme type

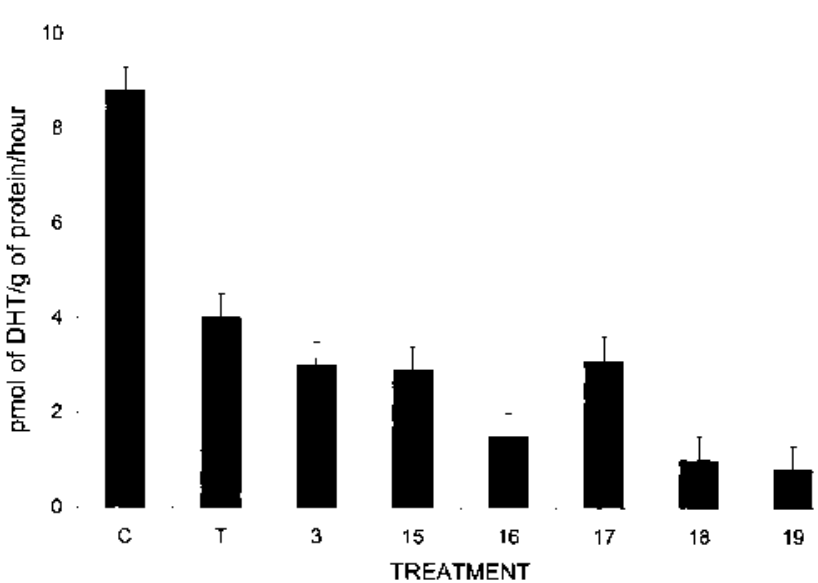

Fig. 4. Effect of Different Synthetic Steroids on in Vitro Conversion of $\left[{ }^{3} \mathrm{H}\right] \mathrm{T}$ to $\left[{ }^{3} \mathrm{H}\right] \mathrm{DHT}$ in Castrated Male Hamster Flank Organs

2. The most effective compound showing the highest inhibitory effect for $5 \alpha$-reductase enzyme was steroid 19 having the lowest value of the weight of the seminal vesicles $(202 \mathrm{mg}){ }^{18,19)}$ In the flank organs, both types of $5 \alpha$-reductase enzyme are present, however the type 1 enzyme predominates. On the other hand, in the seminal vesicles the predominant enzyme is type 2 and therefore it is not possible to compare rigorously both experiments.

Conversion of $T$ to DHT Since the weight of the seminal vesicles depends on the $5 \alpha$-reduced androgens, ${ }^{19)}$ it was important to determine the effect of the new steroids 15-19 on the conversion of $\mathbf{1}$ to $\mathbf{2}$ in vitro metabolism of $\left[{ }^{3} \mathrm{H}\right] \mathrm{T}$ to $\left[{ }^{3} \mathrm{H}\right] \mathrm{DHT}$ in seminal vesicles homogenates of castrated male hamsters.

The extracts from castrated male hamster seminal vesicles were subjected to TLC analysis. The zone corresponding to the 2 standard ( $R f$ value 0.34 ) of each experimental chromatogram was eluted and the radioactivity determined. The results obtained from two separate experiments, performed in duplicate (Fig. 4) demonstrated a significant difference $(p<0.05)$ between the conversion of $\left[{ }^{3} \mathrm{H}\right] \mathrm{T}$ to $\left[{ }^{3} \mathrm{H}\right] \mathrm{DHT}$ in the $\mathrm{T}$ plus finasteride 3 -treated animals expressed as pmol of $\mathrm{DHT} / \mathrm{g}$ of protein $/ \mathrm{h}$, thus indicating that finasteride 3 is a 
good inhibitor for the conversion of T 1 to DHT 2 at pH 6.

The effect of different steroidal structures on the rate of DHT formation is given in Fig. 4. Compounds 15 and 17 showed a higher in vitro conversion of 1 to $2(p<0.05)$ than the other steroids. On the other hand, compounds 16, 18 and 19 exhibited a lower DHT conversion than the 1 plus finasteride 3 treated animals thus showing a high $5 \alpha$-reductase inhibitory activity.

\section{Discussion}

This study reports the $5 \alpha$-reductase inhibitory effect of $16 \beta$-methyl substituted-4,6-pregnadiene-3,20-dione derivative 15, a 6,7-epoxy-16 $\beta$-methyl substituted 4-ene-3,20dione derivative 16, a 6-bromo-16 $\beta$-methyl-17 $\alpha$-valeroyloxypregnadiene-3,20-dione compound $\mathbf{1 7}$ and the trienedienone derivatives $\mathbf{1 8}$ and $\mathbf{1 9}$.

As can be seen in Table 1 (diameter of the pigmented spot on the flank organs), finasteride decreases the diameter of the spot $(3 \mathrm{~mm})$ and thus shows a high inhibitory effect for the enzyme $5 \alpha$-reductase type 2 , a fact previously reported by other authors. ${ }^{18)}$ Furthermore, this compound has also been shown to inhibit hair loss and improves hair growth. ${ }^{19,20)}$ These results could be related to the presence of $5 \alpha$-reductase enzyme type 2 in the hair follicles as previously reported. ${ }^{21)}$ Compounds 15-19 decreased also the diameter of the pigmented spot, and this fact indicates that these compounds are also efficient inhibitors for the $5 \alpha$-reductase enzyme present in the flank organs. The triene-dione ester 19 exhibited the highest activity probably due to the presence of the 3 double bonds and the $\mathrm{C}-17$ ester group.

Table 1 also shows the $5 \alpha$-reductase inhibitory effect of steroids $\mathbf{1 5}-\mathbf{1 9}$ related to the weight of the seminal vesicles of castrated male hamsters treated with $\mathbf{1}$ and a combination of 1 with finasteride 3 . These data clearly indicate that compounds 15-19 decreased the weight of the seminal vesicles as compared to the $\mathrm{T}$ treated hamsters, thus showing an antiandrogenic effect; steroids 16, 18 and 19 exhibited the highest activity. The high antiandrogenic effect of 16, 18 and 19 could also involve inhibition of the synthesis and/or release of pituitary gonadotropins. ${ }^{22}$ )

Figure 4 shows the conversion of $\left[{ }^{3} \mathrm{H}\right] \mathrm{T}$ to $\left[{ }^{3} \mathrm{H}\right] \mathrm{DHT}$ expressed as pmoles of protein per hour. In the control animals (C) (vehicle treated), the weight of the seminal vesicles decreased after $15 \mathrm{~d}$ of castration thus showing the effect of orchidectomy.

As can be seen from Fig. 4, the trienones 18 and 19 and the epoxy compounds $\mathbf{1 6}$ showed a higher antiandrogenic effect than the corresponding dienones 14 and $\mathbf{1 5} .^{13,23-25)} \mathrm{Sev-}$ eral years ago, we carried out a theoretical computer assisted study ${ }^{26)}$ with similar compounds. The results from this study indicated that the first step in the inhibition of the enzyme $5 \alpha$-reductase consists in the formation of an enzyme-antiandrogen activated complex. In a subsequent step, the nucleophilic portion of the enzyme (amino group) attacks the conjugated double bond of the steroid in a Michael type addition reaction to form an irreversible adduct. This explain very well the higher biological activity of the trienones 18 and 19 as compared to the dienones $\mathbf{1 4}$ and $\mathbf{1 5}$. The trienones havig a more coplanar structure react faster with the nucleophilic portion of the enzyme in a Michael type addition reaction than the dienones.
This hypothesis explains also the fact that $17 \alpha$-acetoxy6-methylenepregn-4-ene-3,20-dione has much higher antiandrogenic activity than the corresponding $17 \alpha$-acetoxy pregna-4,6-diene-3,20-dione, both compounds previously synthesized by Petrow. ${ }^{27}$ The 6-methylene compound having an exocyclic double bond can reacts much easier with the nucleophilic part of the enzyme than the corresponding endocyclic 4,6-dienone.

In the case of the active compound $\mathbf{1 6}$, it is also possible that the nucleophilic portion of the enzyme reacts with the electrophilic carbon C-7 of the oxiran ring with a subsequent opening of the epoxy ring with the concomitant formation of a stable steroid-enzyme adduct. As a result of this, the enzyme $5 \alpha$-reductase is inhibited; this reaction explains the high pharmacological activity of the epoxy compound $\mathbf{1 6}$.

At the present time, we are synthesizing several new exocyclic and endocyclic dienones and trienones with the purpose of clarifying this hypothesis. The intermediates 9-14 as well as starting material $\mathbf{8}$ showed a low pharmacological activity.

\section{Experimental}

Chemical and Radioactive Material Solvent were laboratory grade or better. Melting points were determined on a Fisher John's melting point apparatus and are uncorrected. ${ }^{1} \mathrm{H}$ - and ${ }^{13} \mathrm{C}$-NMR spectra were taken on Varian Gemini 200 and VRX-300 spectrometers respectively. Chemical shifts are given in ppm relative to that of $\mathrm{Me}_{4} \mathrm{Si}(\delta=0)$ in $\mathrm{CDCl}_{3}$. The abbreviations of signal patterns are as follows: s, singlet; d, doublet; $t$, triplet; m, multiplet. High resolution mass spectra were recorded on a HP5985-B spectrometer, IR spectra were recorded on a Perkin Elmer 549-B and the UV spectra on a Perkin Elmer 200s spectrometers. Finasteride was obtained from the commercially available Proscar. The tablets were crushed, extracted with chloroform and the solvent was eliminated in vacuum; the crude product was purified by silica gel column chromatography.

$\left(1,2,6,7-{ }^{3} \mathrm{H}\right) \mathrm{T}\left(\left[{ }^{3} \mathrm{H}\right] \mathrm{T}\right.$, specific activity: $\left.95 \mathrm{Ci} / \mathrm{mmol}\right)$ was provided by New England Nuclear Co. (Boston, MA, U.S.A.). Radioinert T and $5 \alpha$-DHT were supplied by Steraloids (Wilton, NH, U.S.A.). Sigma Chemical Co. supplied $\mathrm{NADPH}^{+}$.

Animals and Tissues Adult male Syrian Golden hamsters (150-200 g) were obtained from the Metropolitan University-Xochimilco of Mexico. The animals were kept in a room with controlled temperature $\left(22^{\circ} \mathrm{C}\right)$ and lightdark periods of $12 \mathrm{~h}$. Food and water were provided ad libitum.

Gonadectomies were performed under light ether anesthesia $30 \mathrm{~d}$ before treatments. Animals were sacrificed by ether anesthesia. The seminal vesicles were immediately removed, blotted and weighed prior to their use. Tissues used in the metabolic experiment were homogenized with a tissue homogenizer (model 985-370; variable speed 5000-30000 rpm, Biospec Products Inc.).

Flank Organ Test The flank organ test was performed as previously reported. ${ }^{16)}$ The effect of the new steroids on the flank organs of male hamsters, which were gonadectomized $30 \mathrm{~d}$ before the experiments, was determined on 8 groups of 4 animals/experiment, selected at random.

Daily subcutaneous injections of $200 \mu \mathrm{g}$ of the steroids 15-19 dissolved in $200 \mu \mathrm{l}$ of sesame oil were administered for $6 \mathrm{~d}$ together with $200 \mu \mathrm{g}$ of T. Three groups of animals were kept as control, one was injected with $200 \mu \mathrm{l}$ of sesame oil, the second with $200 \mu \mathrm{g}$ of $\mathrm{T}$ for $6 \mathrm{~d}$ and the third with $\mathrm{T}$ plus finasteride. After this treatment, the animals were sacrificed by ether anesthesia. Both flank organs of the animals were shaven and the diameter of the pigmented spot was measured. The results were analyzed using one way of variance with Epistat software.

Seminal Vesicles Test The effect of the synthesized steroids on the seminal vesicles from castrated male hamsters was determined. After the sacrifice, the seminal vesicles were dissected out and weighed on a balance. Two separate experiments were performed for each group of steroid-treated animals. The results were analyzed using one way of variance with Epistat software.

In Vitro Metabolic Studies with Seminal Vesicles Homogenates from male hamsters seminal vesicles (around $29 \mathrm{mg}$ of protein) were prepared from castrated adult male animals, using Krebs-Ringer buffer solution at $\mathrm{pH}$ of 6 . Tissue preparations were incubated ${ }^{13)}$ in duplicate with $2.3 \mu \mathrm{C}\left[{ }^{3} \mathrm{H}\right] \mathrm{T}$ in 
the presence of $1 \mathrm{~mm} \mathrm{NADPH}^{+}, 8.7 \mu \mathrm{M}$ of finasteride 3 and compounds $15-19$ in a Dubnoff metabolic incubator at $37^{\circ} \mathrm{C}$ for $60 \mathrm{~min}$ in the presence of air. The final incubation volume was $3 \mathrm{ml}$. Incubations without tissues were used as controls. Incubation was terminated by addition of dichloromethane and the $\left[{ }^{3} \mathrm{H}\right]$ steroid was extracted (4X) using 3 vol. of dichloromethane. The protein content of the homogenates was determined by the Bradford's dye-binding method ${ }^{28)}$ using bovine serum albumin (BSA) as the standard.

The isolated compound was purified with steroid carriers (T, DHT) in a thin-layer chromatographic system (chloroform-acetone, 9:1). The non-radioactive steroid carriers were located by ultraviolet lamp $(254 \mathrm{~nm})$ and by spraying with phosphomolybdic acid reagent $8 \%$ in methanol followed by heating. The region containing DHT was scraped off the TLC plate, eluted with methanol and the solvent evaporated under $\mathrm{N}_{2}$ atmosphere. The extract was resuspended in $1 \mathrm{ml}$ of methanol and aliquots were taken to determine the radioactivity in a Packard 3255 liquid scintillation spectrometer, using Ultima Gold (Packard, Downers Grove, IL, U.S.A.) as the counting solution. The counting efficiency of ${ }^{3} \mathrm{H}$ was $47 \%$. The loss of radioactivity during the procedure was calculated in agreement with the results obtained from control experiment without tissue. The formation of DHT was calculated and expresses as $\mathrm{pmol}$ of $\mathrm{DHT} / \mathrm{g}$ protein $/ \mathrm{h}$.

Synthesis of the Steroidal Compounds The synthesis of the intermediates 9-14 (Fig. 2) is given in refs. 23 and 24. The preparation of the new compounds $15-19$ is briefly described below.

$16 \beta$-Methyl-17 $\alpha$-valeroyloxypregna-4,6-diene-3,20-dione 15 A solution containing steroid $14(1 \mathrm{~g}, 2.82 \mathrm{mmol})$, PTS $(10 \mathrm{mg})$, trifluoroacetic anhydride $(8.92 \mathrm{~g}, 42.48 \mathrm{mmol})$ and valeric acid $(1.41 \mathrm{~g}, 13.79 \mathrm{mmol})$ was stirred for $1.5 \mathrm{~h}$ at room temperature (nitrogen atmosphere). The reaction mixture was neutralized with an aqueous sodium bicarbonate solution to a $\mathrm{pH}$ of 7 and diluted with chloroform $(10 \mathrm{ml})$. The organic phase was separated and dried over anhydrous sodium sulfate, the solvent was eliminated in vacuum and the crude product was purified by silica gel column chromatography. Hexane-ethyl acetate $(8: 2)$ eluted $0.84 \mathrm{~g}, 1.97 \mathrm{mmol}(70 \%)$ of pure product 15. mp $147-149^{\circ} \mathrm{C}$. UV $(\mathrm{nm}): 283(\varepsilon=23200)$. IR $(\mathrm{KBr}) \mathrm{cm}^{-1}$ : 1726, 1710, 1665, 1618. ${ }^{1} \mathrm{H}-\mathrm{NMR}\left(\mathrm{CDCl}_{3}\right) \delta: 0.87(3 \mathrm{H}, \mathrm{s}), 0.95(3 \mathrm{H}, \mathrm{t}$, $J=4 \mathrm{~Hz}), 1.10(3 \mathrm{H}, \mathrm{s}), 1.37(3 \mathrm{H}, \mathrm{d}, J=6 \mathrm{~Hz}), 1.66(4 \mathrm{H}, \mathrm{m}), 1.99(3 \mathrm{H}, \mathrm{s})$, $2.44(2 \mathrm{H}, \mathrm{t}, J=3 \mathrm{~Hz}), 6.21\left(2 \mathrm{H}, \mathrm{dd}, J_{1}=4 \mathrm{~Hz}, J_{2}=2 \mathrm{~Hz}\right), 6.28(1 \mathrm{H}, \mathrm{s}) .{ }^{13} \mathrm{C}-$ NMR $\left(\mathrm{CDCl}_{3}\right) \delta: 15.0\left(\mathrm{CH}_{3}\right.$ at C-16), $16.3(\mathrm{C}-18), 19.9(\mathrm{C}-19) 22.2(\mathrm{C}-21)$, 124.1 (C-4), 128.3 (C-6), 141.2 (C-7), 163.3 (C-5), 173.3 (ester carbonyl), 200.3 (C-3), $204.6(\mathrm{C}-20)$. MS ( $\mathrm{m} / \mathrm{z}): 426\left(\mathrm{M}^{+}\right)$.

(6R,7S)-Epoxy-16 $\beta$-methyl-17 $\alpha$-valeroyloxypregn-4-ene-3,20-dione 16 A solution of steroid $15(1 \mathrm{~g}, 2.35 \mathrm{mmol})$ and $m$-chloroperbenzoic acid $(1.5 \mathrm{~g}, 8.69 \mathrm{mmol})$ in chloroform $(40 \mathrm{ml})$ was allowed to reflux for $4 \mathrm{~h}$. The reaction mixture was neutralized with an aqueous sodium bicarbonate solution to $\mathrm{pH}$ of 7 . The organic phase was separated and dried over anhydrous sodium sulfate; the solvent was eliminated in vacuum and the crude product was purified by silica gel column chromatography. Hexane-ethyl acetate $(7: 3)$ eluted $0.73 \mathrm{~g}, 1.65 \mathrm{mmol}(70 \%)$ of the pure product $16 . \mathrm{mp} 158$ $160{ }^{\circ} \mathrm{C}$. UV $(\mathrm{nm}): 240(\varepsilon=14800)$. IR $(\mathrm{KBr}) \mathrm{cm}^{-1}: 1728,1706,1678 .{ }^{1} \mathrm{H}-$ $\operatorname{NMR}\left(\mathrm{CDCl}_{3}\right) \delta: 0.71(3 \mathrm{H}, \mathrm{s}), 0.99(3 \mathrm{H}, \mathrm{t}, J=4 \mathrm{~Hz}), 1.12(3 \mathrm{H}, \mathrm{s}), 1.40(3 \mathrm{H}$, d, $J=5 \mathrm{~Hz}), 1.56(4 \mathrm{H}, \mathrm{m}), 1.93(3 \mathrm{H}, \mathrm{s}), 2.37(2 \mathrm{H}, \mathrm{t}, J=3 \mathrm{~Hz}), 3.38(1 \mathrm{H}, \mathrm{dd}$, $\left.J_{1}=4 \mathrm{~Hz}, J_{2}=3 \mathrm{~Hz}\right), 3.44(1 \mathrm{H}, \mathrm{d}, J=4 \mathrm{~Hz}), 6.17(1 \mathrm{H}, \mathrm{s}){ }^{13} \mathrm{C}-\mathrm{NMR}\left(\mathrm{CDCl}_{3}\right)$ $\delta: 15.4\left(\mathrm{CH}_{3}\right.$ at C-16), $17.3(\mathrm{C}-18), 20.0(\mathrm{C}-19), 28.5(\mathrm{C}-21), 62.2(\mathrm{C}-6)$, 72.3 (C-7), 131.8 (C-4), 162.2 (C-5), 175.2 (ester carbonyl), 199.8 (C-3), $205.3(\mathrm{C}-20)$. MS $(\mathrm{m} / \mathrm{z}): 443\left(\mathrm{M}^{+}\right)$.

6-Bromo-16 $\beta$-methyl-17 $\alpha$-valeroyloxypregna-4,6-diene-3,20-dione 17 A solution of steroid $16(1 \mathrm{~g}, 2.26 \mathrm{mmol})$ and hydrobromic acid $(4.16 \mathrm{ml}$, $48 \%)$ in acetic anhydride $(6.6 \mathrm{ml})$ was stirred at room temperature for $24 \mathrm{~h}$. To the reaction mixture was added ice and the precipitated product was filtered off; it was purified by silica gel column chromatography. Hexane-ethyl acetate $(7: 3)$ eluted $0.81 \mathrm{~g}, 1.60 \mathrm{mmol}(71 \%)$ of the pure product $17 \mathrm{mp}$ $170-172^{\circ} \mathrm{C}$. UV $(\mathrm{nm}): 285(\varepsilon=22900)$. IR $(\mathrm{KBr}) \mathrm{cm}^{-1}: 1726,1702,1679$, 590. ${ }^{1} \mathrm{H}-\mathrm{NMR}\left(\mathrm{CDCl}_{3}\right) \delta: 0.78(3 \mathrm{H}, \mathrm{s}), 0.9(3 \mathrm{H}, \mathrm{t}, J=4 \mathrm{~Hz}), 1.0(3 \mathrm{H}, \mathrm{s}), 1.3$ $(3 \mathrm{H}, \mathrm{d}, J=6 \mathrm{~Hz}), 1.6(4 \mathrm{H}, \mathrm{m}), 1.9(3 \mathrm{H}, \mathrm{s}), 2.4(2 \mathrm{H}, \mathrm{t}, J=4 \mathrm{~Hz}), 6.3(1 \mathrm{H}, \mathrm{s})$, $6.6(1 \mathrm{H}, \mathrm{m}) .{ }^{13} \mathrm{C}-\mathrm{NMR}\left(\mathrm{CDCl}_{3}\right) \delta: 15.5(\mathrm{C}-18), 16.5\left(\mathrm{CH}_{3}\right.$ at $\left.\mathrm{C}-16\right), 19.2(\mathrm{C}-$ 19), 28.5 (C-21), 127.5 (C-4), 147.5 (C-7), 159.6 (C-6), 161.8 (C-5), 175.6 (ester carbonyl), $199.6(\mathrm{C}-3), 202.6(\mathrm{C}-20)$. MS $(\mathrm{m} / \mathrm{z}): 505\left(\mathrm{M}^{+}\right)$.

$17 \beta$-Hydroxy-16 $\alpha$-methylpregna-1,4,6-triene-3,20-dione 18 A solution of steroid $13(1 \mathrm{~g}, 2.82 \mathrm{mmol})$ and DDQ $(2.2 \mathrm{~g})$ in dioxan $(50 \mathrm{ml})$ was allowed to reflux for $4 \mathrm{~d}$. Upon cooling, the precipitated 2,3-dichloro-5,6-dicyanohydroquinone was filtered off. To the filtrate was added $3 \%$ aqueous sodium hydroxide solution $(100 \mathrm{ml})$ and chloroform $(100 \mathrm{ml})$; the mixture was stirred for $5 \mathrm{~min}$. The organic phase was washed 3 times with $3 \%$ aqueous sodium hydroxide solution and water. It was dried over anhydrous sodium sulfate and the solvent removed in vacuum. The crude product was purified by silica gel column chromatography. Hexane-ethyl acetate $(6: 4)$ eluted $640 \mathrm{mg}, 1.88 \mathrm{mmol}(65 \%)$ of the pure product $18 \mathrm{mp} 198-200^{\circ} \mathrm{C}$. UV (nm): 222, 255, 298 ( $\varepsilon=14900,12700,17900$ respectively). IR (KBr) $\mathrm{cm}^{-1}: 3387,1705,1656,1602 .{ }^{1} \mathrm{H}-\mathrm{NMR}\left(\mathrm{CDCl}_{3}\right) \delta: 0.78(3 \mathrm{H}, \mathrm{s}), 1.1(3 \mathrm{H}$, s), $1.3(3 \mathrm{H}, \mathrm{d}, J=4 \mathrm{~Hz}), 2.0(3 \mathrm{H}, \mathrm{s}), 6.0(1 \mathrm{H}, \mathrm{s}), 6.2(1 \mathrm{H}, \mathrm{d}, J=2 \mathrm{~Hz}), 6.4$ $(1 \mathrm{H}, \mathrm{d}, J=3 \mathrm{~Hz}), 6.6(1 \mathrm{H}, \mathrm{d}, J=3 \mathrm{~Hz}), 7.1(1 \mathrm{H}, \mathrm{d}, J=2 \mathrm{~Hz}) .{ }^{13} \mathrm{C}-\mathrm{NMR}$ $\left(\mathrm{CDCl}_{3}\right) \delta: 15.0(\mathrm{C}-18), 16.2\left(\mathrm{CH}_{3}\right.$ at C-16), $20.5(\mathrm{C}-19), 26.5(\mathrm{C}-21), 78.2$ (C-17), 186.2 (C-3), 217.0 (C-20). MS (m/z): $340\left(\mathrm{M}^{+}\right)$.

16 $\beta$-Methyl-17 $\alpha$-valeroyloxypregna-1,4,6-triene-3,20-dione 19 A solution containing steroid $\mathbf{1 8}(1 \mathrm{~g}, 2.94 \mathrm{mmol})$, PTS acid $(10 \mathrm{mg})$ trifluoroacetic anhydride $(8.92 \mathrm{~g}, 42.48 \mathrm{mmol})$ and valeric acid $(1.41 \mathrm{~g}, 13.79$ mmol) was stirred for $1.5 \mathrm{~h}$ at room temperature (nitrogen atmosphere). The reaction mixture was neutralized with an aqueous sodium bicarbonate solution to a $\mathrm{pH}$ of 7 and diluted with chloroform $(10 \mathrm{ml})$. The organic phase was separated and dried over anhydrous sodium sulfate; the solvent was eliminated in vacuum. The crude product was purified by silica gel column chromatography. Hexane-ethyl acetate $(8: 2)$ eluted $840 \mathrm{mg}, 2.03 \mathrm{mmol}$ $(69 \%)$ of the pure product $19 . \mathrm{mp} 149-149^{\circ} \mathrm{C}$. UV (nm): $221,255,300$ ( $\varepsilon=14600,12400,17300$ respectively). IR $(\mathrm{KBr}) \mathrm{cm}^{-1}: 1720,1707,1664$, 1604. ${ }^{1} \mathrm{H}-\mathrm{NMR}\left(\mathrm{CDCl}_{3}\right) \delta: 0.8(3 \mathrm{H}, \mathrm{s}), 1.0(4 \mathrm{H}, \mathrm{m}), 1.3(3 \mathrm{H}, \mathrm{s}), 1.5(3 \mathrm{H}, \mathrm{d}$, $J=4 \mathrm{~Hz}), 1.7(3 \mathrm{H}, \mathrm{t}, J=4 \mathrm{~Hz}), 2.0(3 \mathrm{H}, \mathrm{s}), 2.3(2 \mathrm{H}, \mathrm{t}, J=3 \mathrm{~Hz}), 6.1(1 \mathrm{H}, \mathrm{s})$, $6.2(1 \mathrm{H}, \mathrm{d}, J=2 \mathrm{~Hz}), 6.4(1 \mathrm{H}, \mathrm{d}, J=3 \mathrm{~Hz}), 6.6(1 \mathrm{H}, \mathrm{d}, J=3 \mathrm{~Hz}), 7.1(1 \mathrm{H}, \mathrm{d}$, $J=2 \mathrm{~Hz}) .{ }^{13} \mathrm{C}-\mathrm{NMR}\left(\mathrm{CDCl}_{3}\right) \delta: 15.7\left(\mathrm{CH}_{3}\right.$ at $\left.\mathrm{C}-16\right), 17.6(\mathrm{C}-18), 20.6(\mathrm{C}-$ 19), 83.9 (C-17), 165.3 (C-5), 172.6 (ester carbonyl), 182.2 (C-3), 211.6 (C20). $\operatorname{MS}(\mathrm{m} / \mathrm{z}): 424\left(\mathrm{M}^{+}\right)$.

Acknowledgements We gratefully acknowledge the financial support of DGAPA and Conacyt for the projects IN 204198 and G33450-M.

\section{References}

1) Krieg M., Tunn S., “Testosterone Action, Deficiency, Substitution,” ed. by Nieschlag, Behre H. M., Springer Verlag, Berlin/Heidelberg/New York/London/Paris/Tokyo/Hong Kong/Barcelona, 1990, pp. 219-244.

2) Krieg M., Weiser H., Tunn S., J. Steroid Biochem. Molec. Biol., 53, 395-400 (1995).

3) Tunn S., Hochstrate H., Grunwald I., Flucher ST. H., Krieg M., J. Clin. Endocrinol. Metab., 67, 979—985 (1988).

4) Liang T., Cascieri M., Cheung A., Reynolds G., Rasmusson G., Endocrinology, 117, 571-579 (1985).

5) Gormley G. J., Stoner E., Bruskewiz R. C., Imperato-McGinley J., Walsh P. C., McConnel J. D., Andriole G. L., Geller J., Bracken B., Tenover J. S., Baughan E. D., Pappas F., Taylor A., Binkowitz B., Ng J., Group F. S., N. Engl. J. Med., 327, 1185-1191 (1992).

6) Levy M. A., Brandt M., Heys R., Holt D. A., Metclaff B. W., Biochemistry, 29, 2815-2824 (1990).

7) Horton R., Kato M., Sherino R., Steroids, 10, 245-249 (1967).

8) Clark C., Nowell N., Steroids, 34, 139-149 (1979).

9) Giudici D., Briatico G., Cominato C., J. Ster. Biochem. Mol. Biol., 58, 299-305 (1996).

10) Weisser H., Tunn S., Debus M., Krieg M., Steroids, 59, 616-620 (1994).

11) Andersson S., Berman D. M., Jenkins E. P., Russel D. W., Nature (London), 54, 159-161 (1991).

12) Thigpen A., Russel D. W., J. Biol. Chem., 267, 8577-8583 (1992).

13) Cabeza M., Gutierrez E., Miranda R., Heuze I., Bratoeff E., Flores G., Ramirez E., Steroids, 64, 413-421 (1999).

14) Takayasu S., Adachi K., Endocrinology, 90, 73-80 (1972).

15) Hisoaka H., Ideta R., Seki T., Adachi K., Arch. Dermatol. Res., 283, 269-273 (1991).

16) Vermorken A. J. M., Goos C. M. A., Wirtz P., British J. Dermatol., 106, 99-101 (1982).

17) Cabeza M., Quiroz A., Bratoeff E., Murillo E., Ramirez E., Flores G., Chem. Pharm. Bull., 47, 1232-1236 (1999).

18) Chen C., Puy L. A., Semard S. M., J., Li X., Singh S., Labrie F., J. Invest. Dermatol., 105, 678-682 (1995).

19) Bruchowski N., Wilson J. D., J. Biol. Chem., 243, 2012-2021 (1968).

20) Kaufman K. D., Olsen E. A., Whiting D., Savin R., Bergfeld W., Price V. H., Van Neste D., Roberts J. L., Shapiro J., Binkowitz B., Gormley G. J., J. Am. Acad. Dermatol., 39, 578-589 (1998).

21) Bayne E. K, Flanagan J., Einstein M., Ayala J., Chang B., Azzolina B., Whiting D. A., Mumford R. A., Thiboutot D., Singer I. L., Harris G., British J. Dermatol., 141, 481-491 (1999).

22) Kumar N., Didolkar A. K., Monder C., Bardin W. C., Sundram M., En- 
docrinology, 130, 3677-3683 (1993).

23) Cabeza M., Heuze I., Bratoeff E., Ramirez E., Martínez R., Chem. Pharm. Bull., 49, 525-530 (2001).

24) Bratoeff E., Herrera H., Ramirez E., Solorzano K., Murillo E., Quiroz A., Cabeza M., Chem. Pharm. Bull., 48, 1249-1255 (2000).

25) Bratoeff E., Ramirez E., Murillo E., Flores G., Cabeza M., Curr. Med.
Chem., 6, 1107-1123 (1999).

26) Bratoeff E., Rubio M., Ramirez E., Garcia J., Ramirez G., Chemistry Today, 16, 33-35 (1998).

27) Petrow V., Yueh-sha Wang, Lack L., Steroids, 38, 121-140 (1981).

28) Bradford M. M., Anal. Biochem., 72, 248-254 (1986). 